\title{
Perbanyakan dan Aplikasi PGPR (Plant Growth Promoting Rhizobactheria) di Laboratorium Pengamatan Hama dan Penyakit Banyumas
}

\section{Propagation and Application of PGPR (Plant Growth Promoting Rhizobacteria) at the Banyumas Pest and Disease Observation Laboratory}

\author{
Nada Kholifah ${ }^{1}$, Ardiana Kartika $\mathbf{B}^{2}$, Teguh Pribadi ${ }^{3}$ \\ ${ }^{1,2,3}$ Program Studi Agroteknologi Fakultas Pertanian dan Perikanan \\ Universitas Muhammadiyah Purwokerto
}

\section{ARTICLE INFO}

Article history:

DOI:

$\underline{10.30595 / p s p f s . v 2 i .190}$

Submitted:

July 29, 2021

Accepted:

Sept 10, 2021

Published:

Nov 10, 2021

Keywords:

PGPR, Propagation,

Application

\begin{abstract}
PGPR (Plant Growth Promoting Rhizobacteria) is a substance that helps plant growth with the help of rhizosphere microorganisms. PGPR propagation can be done with liquid media. This PGPR propagation needs to be done because this substance has many benefits for agricultural cultivation. The application of PGPR to the test plant, namely the pakcoy plant, proved that there was an effect of giving PGPR to the plant. Observations on the test plants were carried out by observing several observation variables such as plant height, root length, number of leaves, wet weight and dry weight. The results of these observations showed that the effect on the test plants was seen in the variables of root length, wet weight, and dry weight. Meanwhile, the variable plant height and number of leaves did not show a visible difference.
\end{abstract}

This work is licensed under a Creative Commons Attribution 4.0 International License.

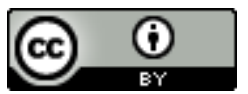

\section{Corresponding Author:}

Nada Kholifah

Program Studi Agroteknologi Fakultas Pertanian dan Perikanan

Universitas Muhammadiyah Purwokerto

Email: nada.kholifah586@gmail.com

\section{PENDAHULUAN}

Dalam usaha pertanian banyak terjadi kendala salah satunya pada pertumbuhan tanaman budidaya yang tidak optimal. Pertumbuhan tanaman dipengaruhi oleh dua faktor yaitu faktor internal dan faktor eksternal. Faktor internal diantaranya meliputi genetik dan hormon. Sedangkan faktor eksternal meliputi cahaya matahari, suhu, air, kelembaban, serangan OPT (Organisme Pengganggu Tanaman), nutrisi (Gardner et al.,1991).

Mikroorganisme yang digunakan dalam pengendalian penyakit salah satunya PGPR (Plant Growth Promoting Rhizobacteria). Penggunaan PGPR sebagai agens hayati untuk mengendalikan penyakit yang disebabkan oleh virus tumbuhan masih sangat sedikit. Beberapa penelitian menunjukkan potensi penggunaan PGPR untuk mengendalikan berbagai jenis penyakit seperti CMV (Cytomegalovirus), tomato mottle virus, dan tobacco necrotic. Dengan ketahanan sistemik diharapkan tanaman tidak mudah diserang penyakit. Aplikasi PGPR diharapkan dapat menginduksi ketahanan sistemik tanaman (Van Loon et al. 1998). Dengan ketahanan sistemik diharapkan tanaman tidak mudah diserang penyakit. 
Menurut Kloepper dan Schroth (1978) kemampuan PGPR sebagai agen pengendalian hayati adalah karena kemampuannya bersaing untuk mendapatkan zat makanan, atau karena hasilhasil metabolit seperti siderofor, hidrogen sianida, antibiotik, atau enzim ekstraseluler yang bersifat antagonis melawan patogen. Selain itu, bakteri PGPR juga berperan dalam melindungi tanaman dari serangan patogen melalui mekanisme antibiosis, parasitisme, atau melalui peningkatan respon ketahanan tanaman (Whipps, 2001).

Bakteri PGPR ini sangat berperan dalam pertumbuhan tanaman selain dalam pengendalian penyakit. Hasil penelitian Masnilah dkk (2009) menunjukkan bahwa perlakuan PGPR dapat meningkatkan pertumbuhan akar tanaman kedelai dibandingkan dengan perlakuan kontrol. Hal ini menyebabkan penyerapan unsur hara dan air dapat dilakukan dengan baik, sehingga kesehatan tanaman juga semakin baik. Dengan semaik baiknya kesehatan tanaman, ketahanan tanaman terhadap tekanan juga akan semakin meningkat. Baik tekanan karena faktor biotik seperti gangguan OPT, maupun tekanan abiotik seperti suhu dan kelembaban. Tujuan penelitian ini yaitu untuk mengetahui cara perbanyakan PGPR sesuai prosedur yang ada di LPHP Banyumas. Selain itu, untuk mengetahui hasil aplikasi PGPR terhadap tanaman caisim.

\section{METODE}

\section{Bahan}

Bahan yang digunakan adalah dedak, akar bambu, air, terasi, gula pasir, micin, media tanam (tanah, batubata, dan arang sekam), PGPR yang sudah jadi, benih pakcoy.

\section{Alat}

Alat yang digunakan adalah panci, gayung, ember, saringan, corong, jerigen, gelas ukur, beaker glass, penggaris, polybag, oven dan alat tulis.

\section{Metode Pelaksanaan}

Penelitian dilaksanakan melalui tiga tahap yaitu tahap persiapan, tahap pelaksanaan dan tahap pengamatan.

\section{Tahap persiapan}

Kegiatan yang dilakukan adalah menyelesaikan seluruh keperluan administrasi dan melengkapi syaratsyarat pelaksanaan penelitian, pengumpulan referensi atau studi pustaka yang berhubungan dengan masalah yang dikaji.

\section{Tahap pelaksanaan}

\section{Persiapan alat dan bahan}

Membersihkan alat yang akan digunakan untuk mengurangi terjadinya kontaminasi dari benda - benda asing yang dapat menyebabkan kegagalan pembuatan PGPR. Bahan - bahan disiapkan dan ditimbang sesuai dengan kebutuhan pembuatan PGPR. Pada akar bambu yang diambil dari dalam tanah, dibersihkan.

Perendaman akar bamboo

Akar bambu yang sudah diambil, kemudian ditimbang seberat 100 gram. Setelah itu direndam pada air 1 liter selama 3 - 4 hari. Air hasil rendaman akan keruh dan berbau masam.

Pembuatan larutan nutrisi

Semua bahan kecuali bahan bambu dimasukkan ke dalam air mendidih dan dimasak selama 15 menit. Kemudian didiamkan selama 1 malam.

Pencampuran bahan

Hasil larutan nutrisi diambil airnya dengan cara diperas. Air rendaman bamboo dicampur dengan larutan nutrisi dengan perbandingan antara 1 : 10. Campuran tersebut dimasukkan ke dalam jerigen dan tutup rapat. Fermentasikan selama 3 - 4 hari dengan stiap hari dikocok agar tidak terjadi endapan.

\section{Pengamatan hasil}

Hasil PGPR yang berhasil adalah terdapatnya gelembung - gelembung pada bagian permukaan dan berbau masam khas hasil fermentasi.

\section{Tahap pengamatan}

PGPR yang sudah jadi diaplikasikan pada tanaman pakcoy berumur 10 hari. Dosis yang dipakai yaitu $10 \mathrm{ml} / 1$ liter air. Tanaman yang diamati terdapat 2 polybag, dengan 1 kontrol dan 1 perlakuan. Setiap polybag terdapat 4 tanaman. Variabel yang diamati diantaranya tinggi tanaman, panjang akar, luas daun, jumlah daun, dan bobot segar. Hasil pengamatan dianalisis dan disajikan dalam bentuk tabel.

\section{HASIL DAN PEMBAHASAN}

\section{Perbanyakan}

1) Inokulasi Akar Bambu

Biang yang digunakan dalam perbanyakan PGPR adalah bakteri yang berasal dari perakaran bambu. Hal ini dipilih karena, perakaran bambu merupakan perakaran yang menguntungkan. Dikatakan menguntungkan 
karena pada tanaman bambu sangat jarang terkena penyakit yang menyebabkan kematian tanaman bambu saat masa pertumbuhan. Pada perakaran bambu terdapat berbagai jenis mikroorganisme perakaran yang menguntungkan. Menurut Pratiwi dkk (2017) dalam akar bambu banyak terdapat bakteri PF (Pseudomonas fluorescens) yang dapat meningkatkan kelarutan unsur P dalam tanah. Rizosfer akar bambu dikolonisasi bakteri Pseudomonas fluorescens (Maryani 2018). Akar bambu banyak terkolonisasi bakteri (Pseudomonas fluorescens), bakteri ini dapat berperan meningkatkan kelarutan $\mathrm{P}$ dalam tanah, Strain tertentu dari Pseudomonas sp. dapat mencegah tanaman dari patogen fungi yang berasal dari tanah Arshad \& Frankenberger (1993 dalam Firmansyah, dkk. 2015:144).

Inokulasi akar bambu dilakukan dengan mengambil akar bambu yang masih segar dan tidak rapuh seperti pada gambar 1. Dengan seperti itu, masih banyak mikroorganisme perakaran yang menempati perakaran tersebut. Setelah diambil, kemudian dibersihkan dari tanah. Akan tetapi tidak dicuci dengan air. Apabila dicuci dengan air, maka bakteri akan banyak yang terlarut dari perakaran sehingga terbuang. Kemudian akar yang sudah dibersihkan dari tanah dipotong kecil - kecil dan dimasukkan ke dalam botol berisi air yang sudah matang. Tujuan dari penggunaan air ini yaitu agar hanya bakteri yang berasal dari perakaran bambu, tidak tercampur dengan bakteri lainnya.

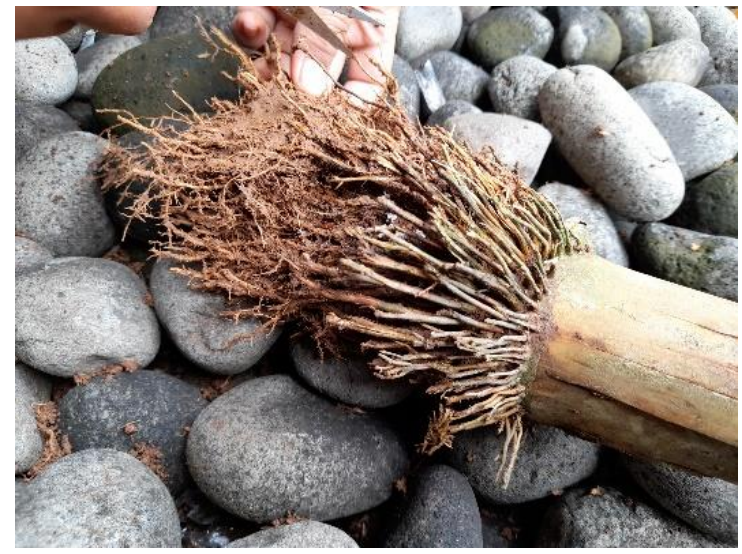

Gambar 1. Akar bambu

Pada perbanyakan PGPR yang dilakukan, dibutuhkan 100 gram akar bambu. 100 gram akar bamboo tersebut direndam pada air 1 liter. Kemudian didiamkan selama 4 hari, sebelum kemudian dicampurkan ke dalam air larutan nutrisi untuk media perbanyakannya. Tujuannya agar bakteri rhizofer dalam akar larut di dalam air sehingga lebih mudah diperbanyak.

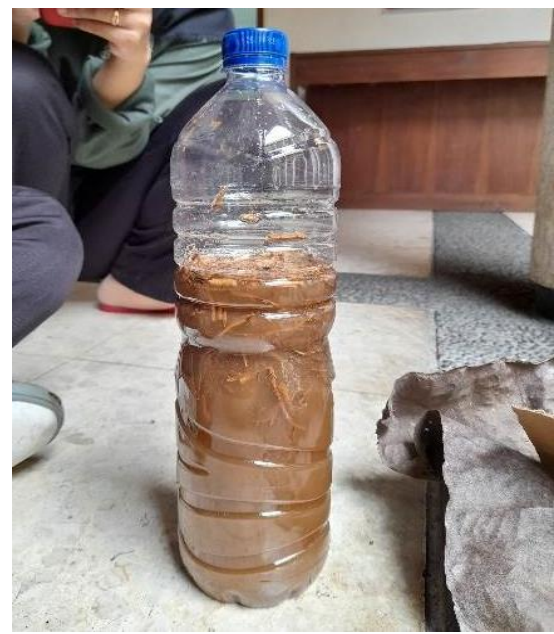

Gambar 2. 100 gram akar bamboo direndam dalam 1 liter air

2) Pembuatan Larutan Nutrisi

Larutan nutrisi yang digunakan berasal dari beberapa bahan diantaranya dedak/bekatul, air bersih, micin, terasi, dan gula pasir. Dedak/bekatul dalam perbanyakan PGPR, akan dimanfaatkan sarinya. Sari dari dedak dan bekatul ini digunakan sebagai media tumbuh bakteri PGPR. Begitupun dengan terasi dan gula pasir. Ketiga bahan tersebut mengandung glukosa dan pati yang digunakan oleh bakteri sebagai bahan makanan. Penggunaan 
micin pada perbanyakan PGPR ini berguna sebagai penambah unsur hara mikro sehingga ketika diaplikasikan pada tanaman, tanaman mendapatkan tambahan unsur hara mikro.

Proses pembuatan larutan nutrisi ini dilakukan dengan memasak semua bahan dengan api sedang. Sebelum dimasak, semua bahan dihaluskan dan dicampur sampai tidak ada gumpalan. Tujuannya agar bahan dapat larut dengan sempurna. Sehingga nutrisi yang ada pada bahan dapat larut dengan air.

Setelah semua bahan tercampur rata, memasak air sebanyak 10 liter dan ditunggu sampai mendidih. Selanjutnya setelah mendidih, masukkan bahan ke dalam air mendidih. Masak selama 15 menit dan tidak lupa untuk diaduk. Setelah 15 menit, matikan kompor. Larutan nutrisi belum bisa langsung dicampurkan dengan biang. Harus didiamkan selama 24 jam. Tujuannya larutan nutrisi tidak panas lagi sehingga memudahkan dalam penyaringan. Apabila pencampuran biang dilakukan ketika larutan masih panas, maka bakteri yang ada pada biang akan mengalami kematian. Sehingga tidak dapat digunakan dengan baik. Tujuan lainnya, agar larutan mengendap.

3) Pencampuran bahan

Setelah dibiarkan selama 24 jam, larutan nutrisi disaring untuk memisahkan larutan nutrisi dengan ampas. Penyaringan dilakukan dengan menggunakan kain saring/kerudung paris. Sehingga didapatkan larutan nutrisi yang agak kental. Hal ini terjadi karena, masih ada dedak/bekatul yang lolos dari kain saring. Cara penyaringan yaitu dengan menuangkan sedikit demi sedikit larutan nutrisi kedalam kain saring. Kemudian kain saring diperas sampai keluar larutan nutrisi semua. Pemerasan dilakukan sampai hanya tersisa ampas dan kering.

Kemudian dilakukan penambahan biang yang sudah dibiarkan selama 4 hari. Larutan nutrisi dimasukkan kedalam wadah kemudian biang disaring untuk memisahkan akar bambunya. Setelah itu dicampur dengan mengaduk larutan nutrisi. Selanjutnya, dimasukkan ke dalam jligen dan ditutup rapat. PGPR ini tidak dapat langsung digunakan, karena bakteri PGPR yang ditambahkan belum berkembang biak. Sehingga diperlukan selama 10 - 14 hari untuk perkembangbiakan bakteri PGPR. Setiap harinya, PGPR yang berada di jilgen dikocok - kocok. Tujuannya agar tidak mengendap dan dapat terurai oleh bakteri.

\section{Hasil Aplikasi}

Pengaplikasian PGPR dilakukan sebanyak 3 kali, yaitu pada tanggal 4 Februari 2021, 11 Februari 2021, dan 16 Februari 2021. Dosis PGPR yang digunakan yaitu $10 \mathrm{ml}$ PGPR untuk 1 liter air. Tanaman uji diamati setelah berumur 16 HST atau 23 HSS yaitu pada saat panen. Pengamatan dilakukan pada tanggal 18 Februari 2021 dan 19 Februari 2021. Perbedaan hasil pemberian PGPR terlihat pada gambar 3.

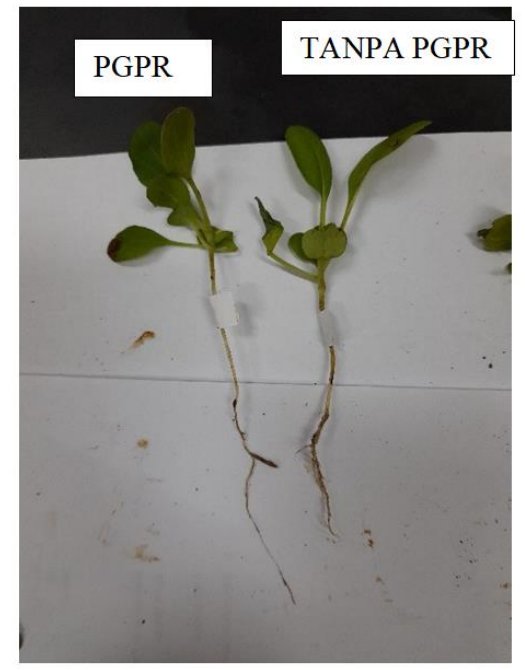

Gambar 3. Perbedaan tanaman dengan pemberian PGPR dan tanpa PGPR

Pengamatan pada tanaman uji dilakukan dengan melakukan pengukuran pada beberapa variabel. Variabel yang diamati berupa tinggi tanaman, jumlah daun, panjang akar, bobot basah, dan bobot kering. Hasil pengamatan pada tanaman uji disajikan dalam bentuk tabel. 
Tabel 1. Tabel Hasil Pengamatan Tanaman Uji

\begin{tabular}{llcc}
\hline \multirow{2}{*}{ No. } & Variabel yang diamati & K (kontrol) & Perlakuan \\
\cline { 3 - 4 } & Tinggi Tanaman & $9,175 \mathrm{~cm}$ & $9,25 \mathrm{~cm}$ \\
2 & Panjang Akar & $2,5 \mathrm{~cm}$ & $5,2 \mathrm{~cm}$ \\
3 & Jumlah Daun & 6 & 6 \\
4 & Bobot Basah & $0,413 \mathrm{gr}$ & $0,6172 \mathrm{gr}$ \\
5 & Bobot Kering & $0,044 \mathrm{gr}$ & $0,073 \mathrm{gr}$ \\
\hline
\end{tabular}

Berdasarkan tabel hasil pengamatan dapat terlihat bahwa selisih tinggi tanaman antara tanaman yang diberi PGPR dengan yang tidak diberi PGPR hanya sedikit yaitu 0,075. Hal ini menunjukkan bahwa, pemberian PGPR pada tanaman pakcoy belum menunjukan pengaruh yang nyata. Hal ini berbeda dengan hasil penelitian Okiwawijaya (2015) dimana konsentrasi PGPR $5 \mathrm{ml} / \mathrm{L}$ pada tanaman selada menunjukkan tanaman selada lebih tinggi dibandingkan dengan konsentrasi yang lain. Pada PGPR mengandung unsur hara makro dan mikro yang dapat meningkatkan pertumbuhan tanaman yan optimal. Diperlukan waktu hinga masa panen sehingga dapat mengetahui perbedaan tinggi tanaman pakcoy yang mungkin terlihat nyata.

Berdasarkan tabel hasil pengamatan, dapat terlihat adanya selisih panjang akar antar tanaman yang tidak diberi PGPR dengan tanaman yang diberi PGPR yaitu 2,7 cm. Hal ini menunjukkan bahwa pemberian PGPR berpengaruh terhadap panjang akar tanaman. PGPR merupakan bakteri yang berkembangbiak di bagian perakaran tanaman. Mutyarny dkk. (2014) menyatakan penggunaan zat pengatur tumbuh seperti auksin dalam PGPR dapat merangsang pembentukan akar pada kondisi tanah masam. Sedangkan menurut Rosyida dan Nugroho (2017) PGPR dapat memacu pertumbuhan tanaman karena kelompok rizobakteria tersebut memiliki kemampuan untuk mensintesis fitohormon, di antaranya adalah indole-3-acetic acid (IAA) atau auksin. Peningkatan akumulasi IAA yang ditimbulkan dari inokulasi PGPR mampu merangsang perpanjangan dan perbesaran sel sehingga berakibat pada peningkatan pertumbuhan rambut akar.

Berdasarkan tabel hasil pengamatan, dapat dilihat pada jumlah daun tidak terjadi pengaruh nyata terhadap pemberian PGPR. Pemberian PGPR tidak menunjukkan adanya perbedaan dengan tanaman yang tidak diberi PGPR. Hal ini sama dengan hasil penelitian oleh Oktafia dan Maghfoer (2018) bahwa pemberian PGPR dan EM4 pada tanaman pakcoy menghasilkan jumlah daun yang tidak berbeda nyata dengan tanaman yang tidak diberi perlakuan (kontrol).

Berdasarkan tabel hasdil pengamatan, didapatkan selisih bobot basah tanaman sebesar 0,259 gr. Dari selisih rata - rata tersebut dapat terlihat bahwa PGPR memberikan pengaruh pada bobot basah tanaman. Aplikasi PGPR dapat meningkatkan bobot kering dan bobot basah tanaman disebabkan oleh inokulasi PGPR yang memberikan pengaruh pada perakaran. Inokulasi PGPR memberikan peningkatan perkembangan akar, sehingga memungkinkan tingkat penyerapan air dan mineral yang lebih baik (Vacheron et al., 2013). Dengan semakin berkembangnya akar tanaman, maka meningkatkan kemampuan akar dan lebih luasnya jangkauan akar dalam menyerap unsur hara dan air. Sehingga kebutuhan unsur hara dan air dalam proses fotosintesis tanaman terpenuhi sehingga fotosintat yang dihasilkan juga lebih optimal. Oleh karena itu, bobot basah tanaman menjadi lebih berat.

Berdasarkan tabel hasil pengamatan, didapatkan selisis berat kering tanaman seberat 0,026 gr. Selisihnya sangat kecil, akan tetapi menunjukkan bahwa pemberian PGPR memberikan pengaruh pada bobot kering tanaman. Kemampuan PGPR dalam merangsang petumbuhan akar, maka dapat meningkatkan hasil fotosintesis tanaman. sehingga berat kering tanaman dapat ditingkatkan dengan adanya pemberian PGPR. Hal ini sejalan dengan penelitian Irfan (2013) yang menyatakan bahwa aplikasi rizobakteri mampu meningkatkan bobot kering umbi bawang merah karena rizobakteri mampu menghasilkan IAA dan dapat berasosiasi dengantanaman serta membantu proses dekomposisi bahan-bahan organik di dalam tanah sehingga penyerapan hara oleh tanaman lebih sempurnayang berpengaruh pada produktivitas tanaman.

\section{KESIMPULAN}

Keberhasilan perbanyakan PGPR dapat terlihat dari adanya gas yang keluar ketika penutup jligen dibuka. Selain itu bau/aroma yang dihasilkan berbau asam hasil fermntasi. Dilihat dari segi warna berwarna kecoklatan. Berdasarkan hasil pengaplikasian PGPR pada tanaman pakcoy, didapatkan hasil bahwa PGPR memberikan pengaruh terhadap panjang akar tanaman pakcoy, bobot basah, dan bobot kering. Sedangkan pada tinggi tanaman dan jumlah daun memberikan hasil yang sama dengan tanaman yang tidak diberi PGPR.

\section{UCAPAN TERIMA KASIH}


Terimakasih kepada pembimbing penelitian di Labolatorium Pengamatan Hama dan Penyakit Banyumas yang telah membimbing selama kegiatan kerja praktik. Selain itu juga terimakasih kepada dosen pembimbing dalam membimbing pelaksanaan kerja praktik pada semester ini.

\section{DAFTAR PUSTAKA}

Gardner, F. P., R. B. Pearce and R. L. Mitchell. 1991. Fisiologi Tanaman Budidaya. Cetakan Pertama. Jakarta : Universitas Indonesia (diterjemahkan oleh : H. Susilo, Subiyanto dan Handayani).

Irfan M.2013.Respon Bawang Merah (Allium ascalonicumL) Terhadap Zat Pengatur Tumbuh Dan Unsur Hara. Agroteknologi .3(2): 35-40.

Kloepper, J. W. dan M. N. Schroth. 1978. Plant Growth-Promoting Rhizobacteria on Radishes In: Proceedings of the 4th International Conference on Plant Pathogenic Bactera. Vol. 2. Station de Pathologie Vegetale et de Phytobacteriologie, INRA, Angers, France, pp.879-882.

Maryani, Y. 2018. Study bamboo root rhizobacteria to growth red onion (Allium ascalonicum L.) variety. Agrivet. 25(2) : 28 - 33 .

Masnilah, R., P. A. Mihardja, dan T. Arwiyanto. 2007. Efektivitas Isolat Bacillus spp. Untuk Mengendalikan Penyakit Busuk Batang Berlubang Erwinia carotovora pada Tembakau di Rumah Kaca. Jurnal Mapeta .9 (3): 154-165.

Mutyarny, E., Endriani dan S.U. Lestari. 2014. Pemanfaatan Urine Kelinci Untuk Mrningkatkan Pertumbuhan dan Produksi Tanaman Sawi (Brassica Juncea L). Jurnal Ilmiah Todakan. 11(2) : 23-34.

Oktafia, T. J. dan Maghfoer, M. D. 2018. Respon Pertumbuhan Dan Hasil Tanaman Pakcoy (Brassica Rapa L.) Terhadap Aplikasi EM dan PGPR. Jurnal Produksi Tanaman. 6(8) : 1974 - 1981.

Onikawijaya, A. 2015. Pengaruh Konsentrasi PGPR Terhadap Pertumbuhan Tanaman Selada (Lactuca sativa L.). Skripsi. Universitas Islam Negeri Sunan Kalijaga. Yogyakarta. p.32.

Pratiwi. F., Marlina \& Mariana, 2017. Pengaruh Pemberian PGPR Akar Bambu terhadap Pertumbuhan dan Hasil Bawang Merah (Allium ascalonicum L.). Agrotropika Hayati, 4(2): 77 - 82.

Rosyidah dan Nugroho, A. S., 2017. Pengaruh Dosis Pupuk Majemuk NPK dan Plant Growth Promoting Rhizobacteria (PGPR) Terhadap Bobot Basah dan Kadar Klorofil Daun Tanaman Pakcoy (Brassica Rapa L.). 6 (2) : $42-56$.

Vacheron, J., Desbrosses G, Bouffaud ML, Touraine B, Moënne Loccoz Y, Muller D, Legendre L, Wisniewski Dyé F, Prigent Combaret C. 2013. Plant growth promoting rhizobacteria and root system functioning.Front Plant Sci. 4:356.

Van Loon LC, Bakker PAHM, Pieterse MJ. 1998. Systemic resistance induced by rhizobacteria. Ann Rev Phytopathol 36: 453 - 483.

Whipps, J. M. 2001. Microbial Interaction and Biocontrol in The Rhizosphere. J Exp Bot. 52(4) : 487- 511. 